\title{
Site Release Report for C-Well Pipeline, UE-25 Large Rocks Test Site, and 29 GSF Test Pits
}

Prepared for:

U.S. Department of Energy

Yucca Mountain Site Characterization Office

P.O. Box 30307

North Las Vegas, Nevada 89036-0307

Prepared by:

Bechtel SAIC Company, LLC

1180 Town Center Drive

Las Vegas, Nevada 89144

Under Contract Number

DE-AC08-01NV12101 


\section{DISCLAIMER}

This report was prepared as an account of work sponsored by an agency of the United States Government. Neither the United States Government nor any agency thereof, nor any of their employees, nor any of their contractors, subcontractors or their employees, makes any warranty, express or implied, or assumes any legal liability or responsibility for the accuracy, completeness, or any third party's use or the results of such use of any information, apparatus, product, or process disclosed, or represents that its use would not infringe privately owned rights. Reference herein to any specific commercial product, process, or service by trade name, trademark, manufacturer, or otherwise, does not necessarily constitute or imply its endorsement, recommendation, or favoring by the United States Government or any agency thereof or its contractors or subcontractors. The views and opinions of authors expressed herein do not necessarily state or reflect those of the United States Government or any agency thereof. 
Site Release Report for C-Well Pipeline, UE-25 Large Rocks Test Site, and 29 GSF Test Pits

Prepared by:

K.q. Rasmeor

K.E. Rasmuson

Approved by:

Suryctare

Manager, Environmental Compliance $\frac{4 / 2 / 02}{\text { Date }}$

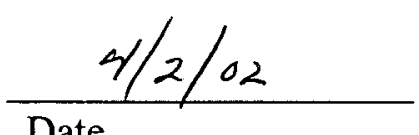

Date 


\section{EXECUTIVE SUMMARY}

The U.S. Department of Energy has implemented a program to reclaim lands disturbed by site characterization at Yucca Mountain. Long term goals of the program are to re-establish processes on disturbed sites that will lead to self-sustaining plant communities. The Biological Opinion for Yucca Mountain Site Characterization Studies required that the U.S. Department of Energy develop a Reclamation Standards and Monitoring Plan to evaluate the success of reclamation efforts. According to the Reclamation Standards and Monitoring Plan, reclaimed sites will be monitored periodically, remediated if necessary, and eventually compared to an appropriate reference area to determine whether reclamation goals have been achieved and the site can be released from further monitoring. Plant cover, density, and species richness (success parameters) on reclaimed sites are compared to 60 percent of the values (success criteria) for the same parameters on the reference area. Small sites (less than $0.1 \mathrm{ha}$ ) are evaluated for release using qualitative methods while large sites (greater than $0.1 \mathrm{ha}$ ) are evaluated using quantitative methods.

In the summer of 2000,31 small sites reclaimed in 1993 and 1994 were evaluated for reclamation success and potential release from further monitoring. Plant density, cover, and species richness were estimated on the C-Well Pipeline, UE-25 Large Rocks test site, and 29 ground surface facility test pits. Evidence of erosion, reproduction and natural recruitment, exotic species abundance, and animal use (key attributes) also were recorded for each site and used in success evaluations. The C-Well Pipeline and ground surface facility test pits were located in a Larrea tridentata - Ephedra nevadensis vegetation association while the UE-25 Large Rocks test site was located in an area dominated by Coleogyne ramosissima and Ephedra nevadensis. Reference areas in the same vegetation associations with similar slope and aspect were chosen for comparison to the reclaimed sites. Sixty percent of the reference area means for density, cover, and species richness were compared to the estimated means for the reclaimed sites.

Plant density, cover, and species richness at the C-Well Pipeline and UE-25 Large Rocks test site were greater than the success criteria and all key attributes indicated the sites were in acceptable condition. Therefore, these two sites were recommended for release from further monitoring. Of the 29 ground surface facility test pits, 26 met the criterion for density, 21 for cover, and 23 for species richness. When key attributes and conditions of the plant community near each pit were taken into account, 27 of these pits were recommended for release. Success parameters and key attributes at ground surface facility test pits 19 and 20 were inadequate for site release. Transplants of native species were added to these two sites in 2001 to improve density, cover, and species richness. 
INTENTIONALLY LEFT BLANK 
CONTENTS

Page

ACRONYMS xiii

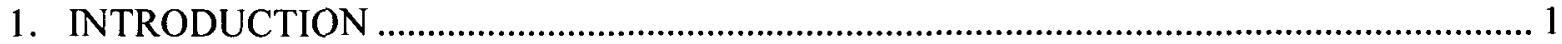

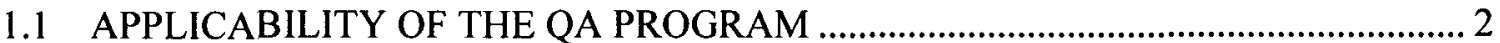

1.2 RECLAMATION STANDARDS AND MONITORING PLAN ................................. 2

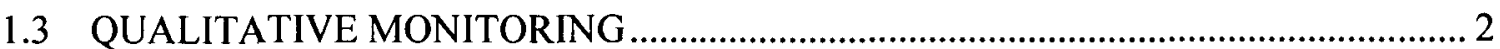

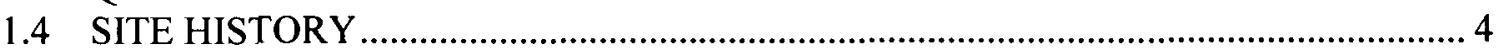

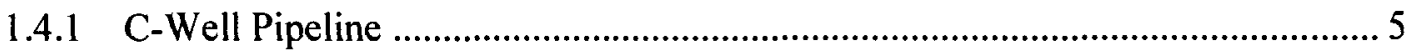

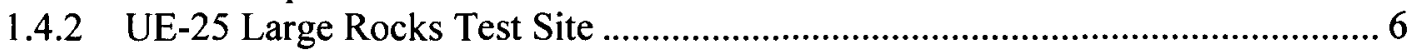

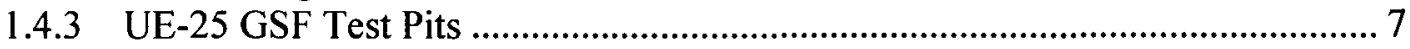

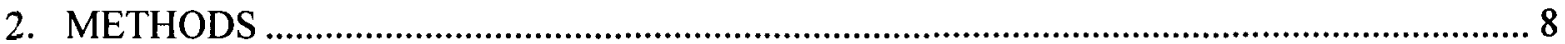

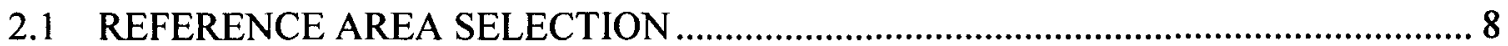

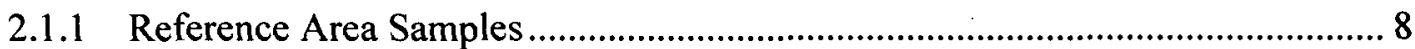

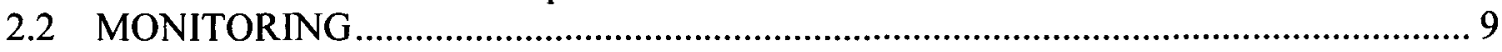

3. RESULTS AND SITE RELEASE RECOMMENDATIONS ......................................... 12

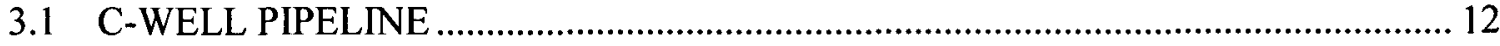

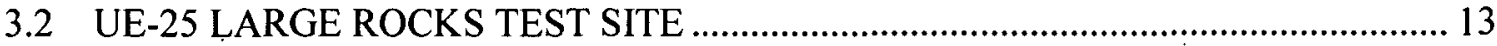

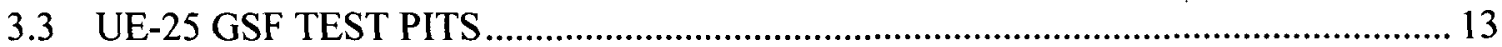

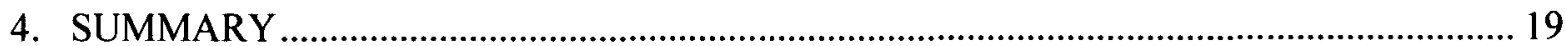

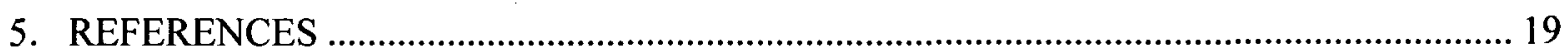

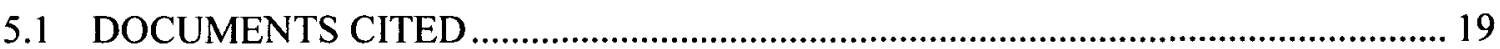

5.2 CODES, STANDARDS, REGULATIONS, AND PROCEDURES .......................... 20

5.3 SOURCE DATA, LISTED BY DATA TRACKING NUMBER ….......................... 21

APPENDIX A - PLANT SPECIES ON RECLAMATION SITES....................................... A-1 
INTENTIONALLY LEFT BLANK 


\section{FIGURES}

Page

1. Yucca Mountain Project Area Map …......................................................................... 1

2. Location of GSF Test Pits, C-Well Water Line, and Associated Reference Areas ............ 4

3. Location of Large Rocks Test Site and Reference Area............................................. 5

4. C-WELL Pipeline in the Summer of 2000, Six Growing Seasons after

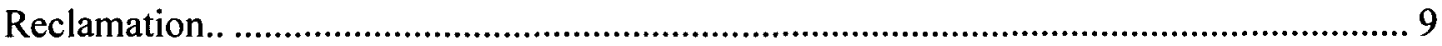

5. Large Rocks Test Site in the Summer of 2000, Six Growing Seasons after

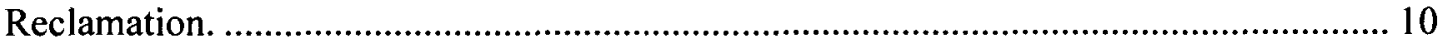

6. UE-25 GSF TP \#24 in the Summer of 2000, Six Growing Seasons after

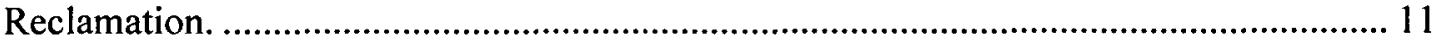

7. UE-25 GSF TP \#20 in the Summer of 2000, Six Growing Seasons after

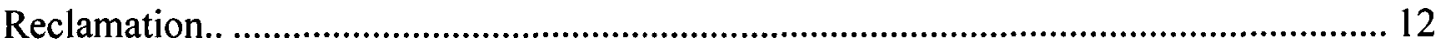

8. Means for a) Density, b) Cover, and c) Species Richness on C-Well Pipeline and Its Associated Reference Area.

9. Means for a) Density, b) Cover, and c) Species Richness on UE-25 Large Rocks Test Site and Its Associated Reference Area

10. Means for a) Density, b) Cover, and c) Species Richness on GSF Test Pits and Their Associated Reference Areas 
INTENTIONALLY LEFT BLANK 


\section{TABLES}

Page

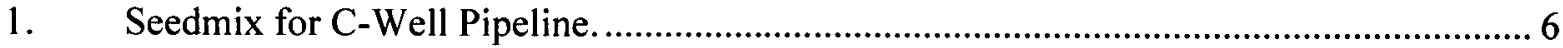

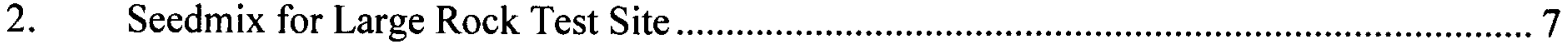

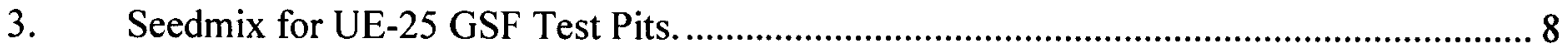

4. Cover, Density, and Species Richness for UE-25 GSF Test Pits for 1998, 1999, and 2000 . 
INTENTIONALLY LEFT BLANK 


\section{ACRONYMS AND ABBREVIATIONS}

$\begin{array}{ll}\text { DOE } & \text { U.S. Department of Energy } \\ \text { GSF } & \text { ground surface facility } \\ \text { ESP } & \text { Ecological Study Plot } \\ \text { PLS } & \text { Pure Live Seed }\end{array}$


INTENTIONALLY LEFT BLANK 


\section{INTRODUCTION}

The U.S. Department of Energy (DOE) has been characterizing Yucca Mountain, Nevada (Figure 1) for the potential development of a monitored geologic repository for spent nuclear fuel and high-level radioactive waste. As a result of these characterization studies, land surface disturbances were created. A program to reclaim areas disturbed by site characterization and supporting activities was implemented to meet environmental requirements set forth by federal laws and regulations. The Biological Opinion for Yucca Mountain Site Characterization Studies (Buchanan 1997) required that DOE develop a Reclamation Standards and Monitoring Plan (Dixon 1998) to evaluate the success of reclamation efforts. Monitoring is necessary to ensure that sites are progressing as desired and to make a final determination regarding reclamation success so that reclaimed sites may be released from further action by DOE. This report describes the success guidelines, monitoring efforts, and results for 31 sites that were reclaimed in 1993 and 1994. The monitoring results are used to support the decision that reclamation was successful for 29 of the sites and that those sites should be released from further monitoring by DOE.

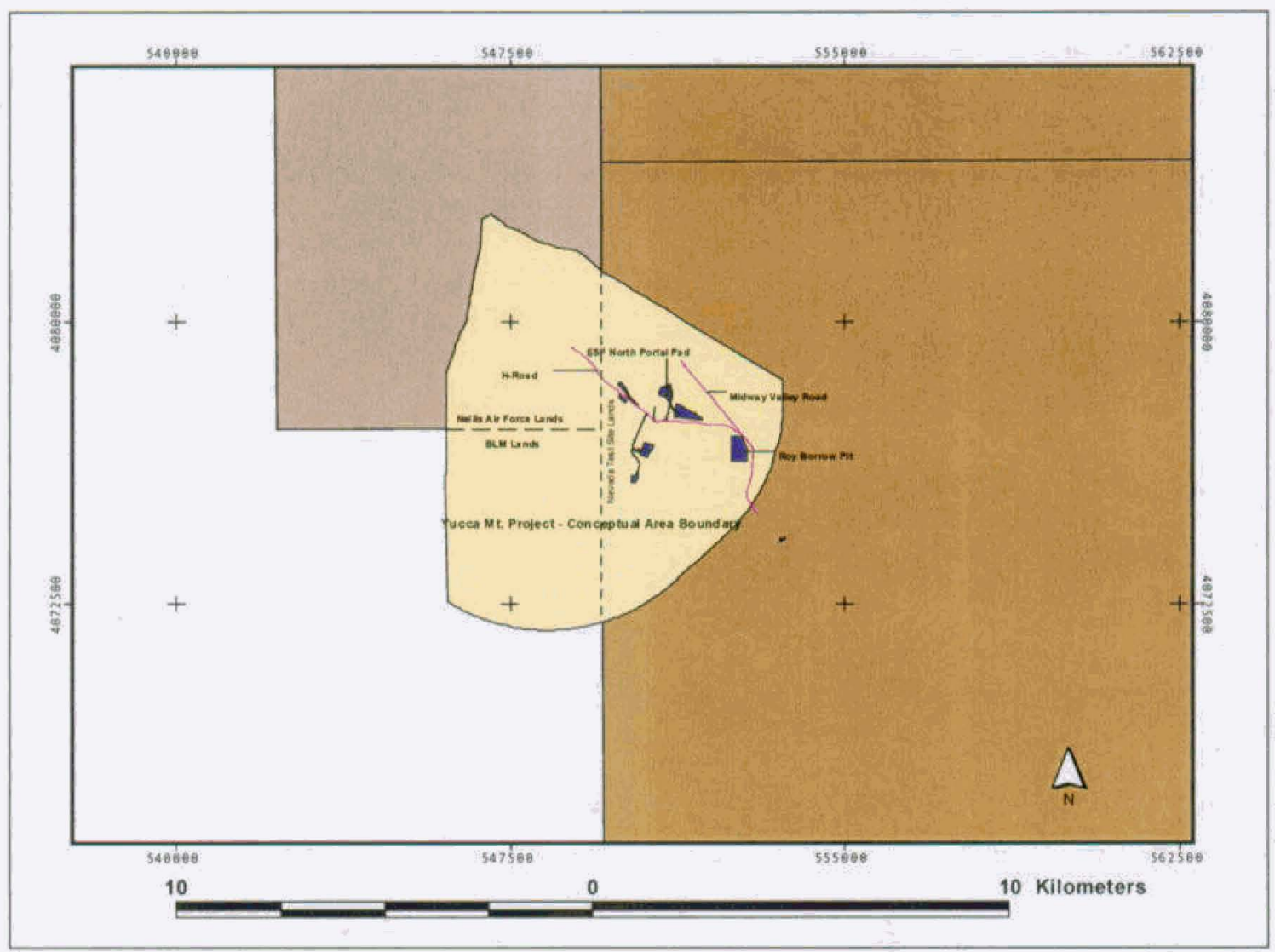

DTN: MO0102COV00340.000

Figure 1. Yucca Mountain Project Area Map 


\subsection{APPLICABILITY OF THE QA PROGRAM}

This report has been determined to be non-quality affecting in accordance with AP-2.21Q, Quality Determinations and Planning for Scientific, Engineering, and Regulatory Compliance Activities. This report is covered by the activity evaluation for terrestrial ecosystem monitoring (CRWMS M\&O 2000). The information will not be used to support any quality affecting activities. Therefore, this report is not subject to the requirements of the Quality Assurance Requirements and Description (DOE 2000).

\subsection{RECLAMATION STANDARDS AND MONITORING PLAN}

The long-term goal for reclamation at Yucca Mountain is to re-establish processes on disturbed sites that will eventually lead to the establishment of self-sustaining plant communities. Techniques are used that attempt to establish structural/physical components, control soil erosion, and facilitate establishment of native vegetation (YMP 2001). To evaluate reclamation success at a given site the following criteria were developed (Dixon 1998):

"Reclamation will be considered successful if the cover, density, and species richness (i.e., the number of perennial plant species in each site) of nativeperennial vegetation is equal to or exceeds 60 percent of the values of these parameters in undisturbed reference areas."

Ecological significance of a disturbance impact is a function of several factors including severity and areal extent (Cole and Landres 1996). Geophysical exploration such as trench or pit excavation creates a locally severe impact (i.e., removal of all vegetation). However, in many cases the areal extent of these disturbances is small, resulting in insignificant impacts when only species that are common to the region are removed. Additionally, undisturbed native vegetation surrounding small sites increases the likelihood of seed dispersal and propagule migration into the site over time. Because impacts caused by small disturbances are of less concern than larger disturbances, less effort is required to adequately monitor small reclaimed sites. For small disturbances $(\leq 0.10 \mathrm{ha}$ ), qualitative observations of success parameters (plant cover, density and species richness) and other key attributes are made during yearly monitoring sessions. In the sixth growing season, these observations are evaluated with respect to an undisturbed reference area to determine whether the site is progressing towards the long-term goal. For sites that are larger than $0.10 \mathrm{ha}$, a more rigorous quantitative approach is taken which includes data collection and statistical comparison to an appropriate reference area. The sites discussed in this report were less than 0.10 ha and therefore qualitative observations were used to evaluate reclamation success.

\subsection{QUALITATIVE MONITORING}

Because monitoring for small sites is qualitative (i.e., estimates and observations), strict adherence to the 60 percent success criteria for site release is not possible, and a certain degree of professional judgement based on ecological processes and relationships is required. For small sites at Yucca Mountain, the presence of certain key attributes are used to help assess whether conditions required for recolonization of vegetation have been established. Once these conditions have been met, established plants contribute to maintenance of the system and it is 
less likely that mitigation will be required for the site to meet the long-term reclamation goal. Key attributes that are monitored in addition to the success parameters include erosion, natural recruitment, reproduction, exotic species abundance, animal use, and pattern of established vegetation (i.e., presence of large interspaces). Lack of erosion at a site provides evidence that soils have been adequately stabilized, while natural recruitment and/or reproduction indicate that important functional processes are in place that initiate regeneration such as pollination and seed dispersal. Exotic species potentially compete with native perennial species and relatively high abundances can have negative effects on site conditions. Evidence of animal use is used as an indicator that habitat conditions have been restored. Pattern of established vegetation helps to determine whether large bare areas are indicative of site conditions or simply a result of the patchiness of the surrounding vegetation (see below). If one or more of these attributes are favorable in the sixth year of monitoring, and all reasonable methods (including remediation) have been employed, a small site may be released even if the 60 percent criteria are not met for all three success parameters (Dixon 1998).

Plant communities generally are not uniform, but instead are patchy on several scales for measures such as density, cover, and species richness (Greig-Smith 1983; Kershaw and Looney 1985). A small site might exhibit a relatively large patch of bare ground that is consistent with the pattern of surrounding vegetation but fails to meet the plant cover or density criteria. Additionally, plant growth and re-establishment may be affected by patches of vegetation, herbivores, or granivore colonies adjacent to the site, rather than by factors specific to the small reclaimed area. In such cases, it would be inappropriate to base a decision regarding site release on the success criteria alone. Lack of soil erosion and/or presence of plant recruitment or reproduction provide evidence that natural processes will move site conditions towards the longterm goal.

Within the above constraints, density is considered most indicative of problems on small sites. Seeding rates and high seedling mortality on reclaimed sites generally result in high initial plant densities that decline over time (CRWMS M\&O 1998). Monitoring data for seven reclaimed sites at Yucca Mountain show steep initial declines in the density of seeded species (CRWMS M\&O 1998). After the fourth or fifth growing season the magnitude of decline lessened significantly as sites progressed towards sustainable densities. If only a few plants are present on a site after six growing seasons, the potential to meet the success criterion for cover is low and erosion potential could be high. Conversely, if plant densities are near or above the 60 percent criterion after six growing seasons those plants will grow and produce more cover over time within the limits imposed by the environment and natural disturbances (e.g., drought and herbivory).

Cover is considered less indicative of a site related problem than density within a six year time period due to yearly and seasonal variability in rainfall. Several shrub species at Yucca Mountain are drought deciduous and dormant for up to eight months out of the year (Smith et al. 1995). Monitoring data from reclamation sites at Yucca Mountain showed that plant cover was low between 1995 and 1997 (a drought period). During the spring of 1998, when unusually high amounts of precipitation were recorded (total precipitation from January to May was about 270 $\mathrm{mm}$ ) sites exhibited increases over existing cover of 45 to 91 percent (CRWMS M\&O 1998). Thus, low cover values during a drought period do not necessarily indicate a site related problem. 
Species richness is an important measure of community stability and function on large areas (Barbour et al. 1980). However, loss of one or two species in a small reclaimed area would have negligible effects on the larger ecosystem and would not compromise the long-term reclamation goal for the site. Attempts are made to maintain species richness on small sites; however, it is not as important in site release decisions as density or the status of other key attributes. Thus, a given observation (success criteria or key attribute) that indicates lack of success is evaluated by the importance of that indicator to the site as well as the magnitude of the problem.

\subsection{SITE HISTORY}

The 31 sites reclaimed in 1993 and 1994 included the C-Well Pipeline Trench, UE-25 Large Rocks Test Site, and 29 UE-25 ground surface facility (GSF) Test Pits (Figures 2 and 3). The 29 GSF Test Pits are discussed together because they were similar disturbances in the same vegetation association located within a relatively small area.

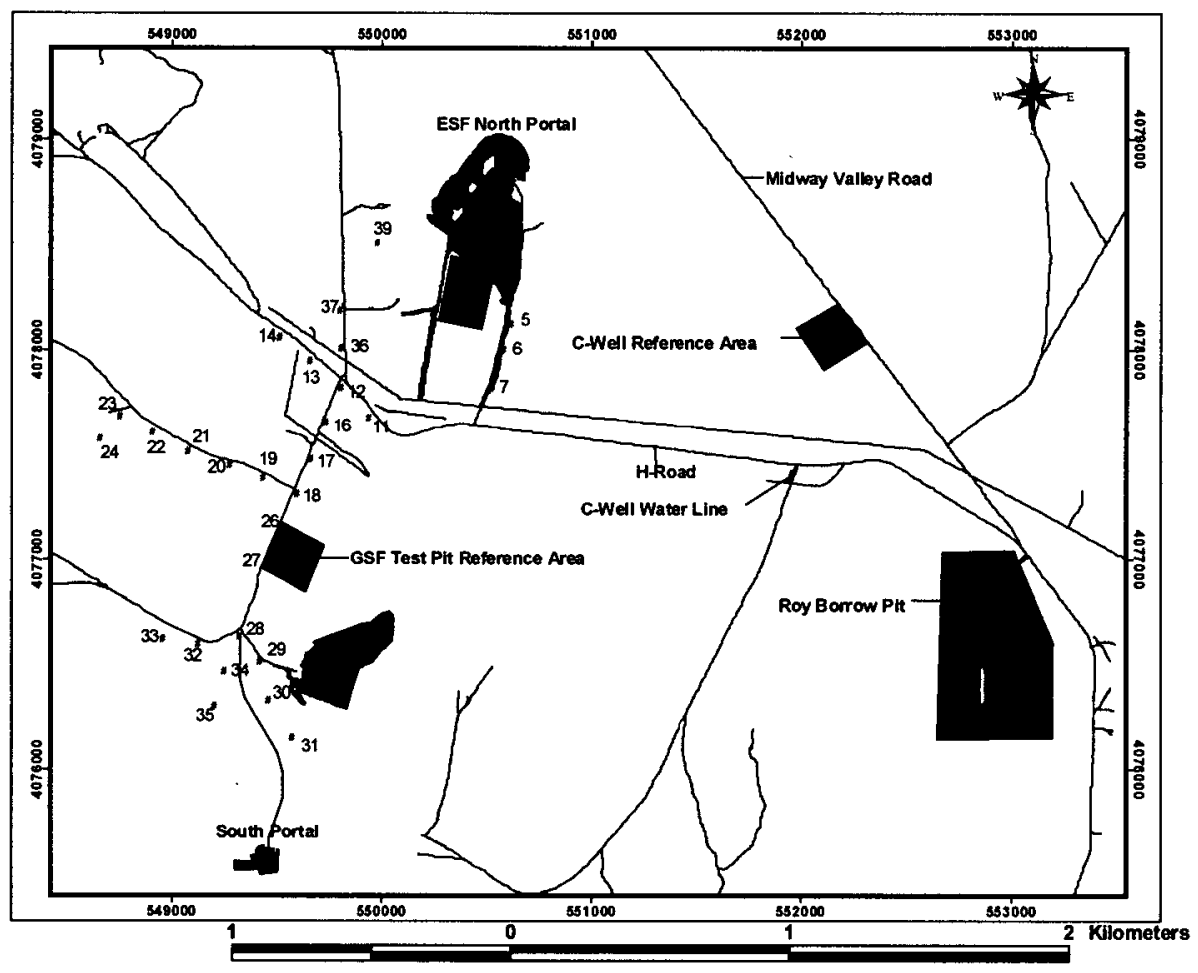

NOTES: Numbers represent the different test pits.

DTN: MO0102COV00340.000

Figure 2. Location of GSF Test Pits, C-Well Water Line, and Associated Reference Areas 


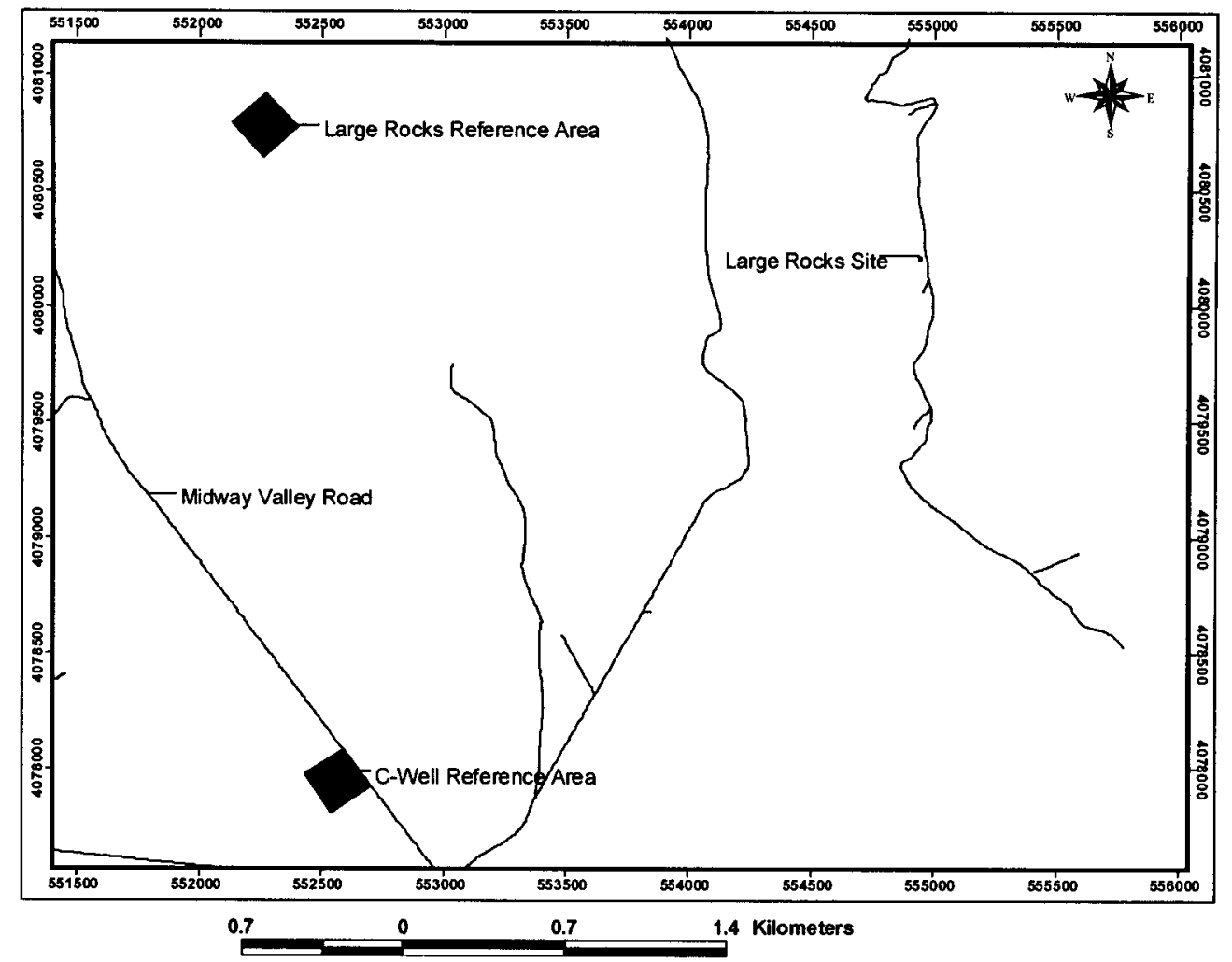

Figure 3. Location of Large Rocks Test Site and Reference Area

DTN: MO0102COV00340.000

\subsubsection{C-Well Pipeline}

In the fall of 1993 a six-inch pipeline was constructed to take discharged water from the UE-25 borehole complex (C-Well complex) to an area in 40-Mile Wash where it could be used to recharge the aquifer. The discharge pipeline was required for a suite of hydraulic tests conducted on the $\mathrm{C}$-Well complex. Construction included digging a trench $(0.064 \mathrm{ha})$ to run the pipeline under $\mathrm{H}$ road at the $\mathrm{C}$-Well intersection (Figure 2). The trench was in a Larrea tridentata Ephedra nevadensis vegetation association with slopes ranging from 0 to 5 percent. During construction of the trench, topsoil was salvaged and placed adjacent to the trench. The trench was backfilled immediately after placing the pipeline.

In December 1994, the area was ripped to alleviate compaction and prepare the seedbed. Ripping was limited to a depth of $15 \mathrm{~cm}$ to avoid damaging the pipeline. The site was broadcast seeded at a rate of $42 \mathrm{~kg} / \mathrm{ha}$ of pure live seed (PLS) (Table 1) and harrowed to cover the seed. The site was mulched with wheat straw at a rate of $3,500 \mathrm{~kg} / \mathrm{ha}$ and crimped. The entire site was fenced with $5 \mathrm{~cm}$ mesh chicken wire to reduce browsing by lagomorphs. Fence height was $90 \mathrm{~cm}$. 
In 1998, 24 L. tridentata (creosotebush) transplants were planted in the site as part of a study of transplanting techniques to increase species diversity for sites that require remediation. Six of the $L$. tridentata transplants survived.

\subsubsection{UE-25 Large Rocks Test Site}

In August 1993, topsoil was removed to expose bedrock at the Large Rocks Test Site located between Calico Hills and Alice Ridge in Area 25 (Figure 3). The topsoil was used to create a level equipment pad adjacent to the scraped area to harvest 15-20 large rocks (approximately $1.5 \times 1 \times 1 \mathrm{~m}$ ) for testing rotary drilling tools and modeling tunnel boring machine performance. After the rocks were extracted the topsoil was redistributed over the site. The area faced southeast and sloped 5 to 10 percent. The dominant species in the area were Coleogyne ramosissima and Ephedra nevadensis. The work disturbed 0.09 ha. In December 1993, the site was broadcast seeded (Table 2). The site was harrowed to cover the seed and mulched with wheat straw at a rate of $2800 \mathrm{~kg} / \mathrm{ha}$. The wheat straw was either tackified with a mixture of Mbinder $(120 \mathrm{~kg} / \mathrm{ha})$ and wood fiber $(100 \mathrm{~kg} / \mathrm{ha})$ or anchored with green netting. The site was fenced with $5 \mathrm{~cm}$ mesh chicken wire to reduce lagomorph browsing. Fence height was $90 \mathrm{~cm}$.

Table 1. Seedmix for C-Well Pipeline

\begin{tabular}{|l|c|c|}
\hline \multicolumn{1}{|c|}{ Plant Species } & Percent of Seedmix & PLS $^{\mathbf{1}}$ (kg /ha) \\
\hline Achnatherum hymenoides & 3 & 1.26 \\
Ambrosia dumosa & 6 & 2.52 \\
Atriplex canescens & 10 & 4.20 \\
Ephedra nevadensis & 20 & 8.40 \\
Ericameria nauseosa & 5 & 2.10 \\
Eriogonum fasciculatum & 5 & 2.10 \\
Larrea tridentata & 5 & 2.10 \\
Hymenoclea salsola & 16 & 6.72 \\
Krascheninnikovia lanata & 5 & 2.10 \\
Lycium andersonii & 15 & 6.30 \\
Sphaeralcea ambigua & 10 & 4.20 \\
\hline
\end{tabular}

NOTES: ${ }^{1}$ PLS - Pure Live Seed. See Table A-2 for plant species common names. 
Table 2. Seedmix for Large Rock Test Site

\begin{tabular}{|l|c|c|}
\hline \multicolumn{1}{|c|}{ Plant Species } & Percent of Seedmix & PLS $^{\mathbf{1}}$ (kg/ha) \\
\hline Achnatherum hymenoides & 5 & 2.1 \\
Ambrosia dumosa & 25 & 10.5 \\
Atriplex canescens & 10 & 4.2 \\
Atriplex confertifolia & 15 & 6.3 \\
Chrysothamnus viscidiflorus & 2.5 & 1.1 \\
Coleogyne ramosissima & 5 & 2.1 \\
Ephedra nevadensis & 10 & 4.2 \\
Ericameria nauseosa & 5 & 2.1 \\
Hymenoclea salsola & 5 & 2.1 \\
Krascheninnikovia lanata & 7.5 & 3.3 \\
Larrea tridentata & 5 & 2.1 \\
Lycium andersonii & 2.5 & 1.1 \\
Sphaeralcea ambigua & 2.5 & 1.1 \\
\hline
\end{tabular}

NOTES: ${ }^{1}$ PLS - Pure Live Seed. See Table A-2 for plant species common names.

\subsubsection{UE-25 GSF Test Pits}

In 1992, 39 soil pits were permitted for excavation between the north and south portals (Figure 2) as part of phase II of the Soil and Rock Property Testing activity. The pits were used to investigate soil profiles, evaluate the ability of the soil to support structures, determine the permeability of soil for leach field design, and evaluate concrete aggregate sources. Pits were spaced approximately $165 \mathrm{~m}$ apart along existing approved roads. All pits were at least $1.7 \mathrm{~m}$ deep with a maximum depth of $5 \mathrm{~m}$. They ranged from $0.8-1.7 \mathrm{~m}$ wide and were up to $6.6 \mathrm{~m}$ long. Disturbed areas around the pits were approximately $15 \times 15 \mathrm{~m}$. Topsoil was salvaged to a maximum depth of $60 \mathrm{~cm}$ during excavation and stored adjacent to the pits. Topsoil was stabilized in October and November 1992. Pits 14, 22, and 31 were on sites that were too rocky for topsoil salvage. All test pits were located in a Larrea tridentata - Ephedra nevadensis vegetation association at an average elevation of $1110 \mathrm{~m}$.

Thirty-five of the 39 test pits required reclamation (Figure 2). Four of the 39 test pits $(1,2,4$, and 15) were either not dug (15) or were covered prior to reclamation by another project disturbance (e.g., construction of the Exploratory Studies Facilities pad and related activities such as access roads). In November 1993, the 35 pits were backfilled and topsoil was replaced. After backfilling, none of the test pits required recontouring because all slopes were less than 5 percent. The total disturbance area for all 35 test pits was 0.74 ha. Seed was broadcast by hand at a rate of $30 \mathrm{~kg}$ PLS/ha (Table 3). The sites were harrowed to cover the seed. Each site was mulched with wheat straw at a rate of $3,500 \mathrm{~kg} / \mathrm{ha}$ and tackified with a mixture of M-binder (120 $\mathrm{kg} / \mathrm{ha})$, wood fiber $(225 \mathrm{~kg} / \mathrm{ha})$ and water $(950 \mathrm{~L} / \mathrm{ha})$.

After reclamation was completed, five of the pits $(3,8,9,10$, and 25$)$ were covered by other project activities (e.g. roads or road widening). Test pit 21 was quantitatively evaluated during development of the reclamation monitoring program in 1998. It was determined at that time that the site met all three success criteria and it was released from further monitoring. The results of reclamation and monitoring on the remaining 29 test pits are reported here. 
In 1998, 429 L. tridentata and Lycium andersonii transplants were placed in the 29 sites as part of a test of transplanting techniques to increase species richness in sites with low diversity. Approximately 60 percent of the transplants of both plant species survived.

Table 3. Seedmix for UE-25 GSF Test Pits

\begin{tabular}{|l|c|c|}
\hline \multicolumn{1}{|c|}{ Plant Species } & Percent of Seedmix & PLS $^{\mathbf{1}}$ (kg/ha) \\
\hline Achnatherum hymenoides & 21.7 & 6.5 \\
Atriplex canescens & 21.7 & 6.5 \\
Atriplex confertifolia & 21.7 & 6.5 \\
Ambrosia dumosa & 8.3 & 2.5 \\
Hymenoclea salsola & 8.3 & 2.5 \\
Larrea tridentata & 10.0 & 3.0 \\
Lycium andersonii & 8.3 & 2.5 \\
\hline
\end{tabular}

NOTES: ${ }^{1}$ PLS - Pure Live Seed. See Table A-2 for plant species common names.

\section{METHODS}

\subsection{REFERENCE AREA SELECTION}

For all 31 sites, Ecological Study Plots (ESPs) were chosen as reference areas. ESPs were established in 1989 to answer questions about the effects of the site characterization process on biological resources and to establish baseline site descriptions. ESPs are 4 ha $(200 \mathrm{~m} \times 200 \mathrm{~m})$, permanent, unfenced plots established at random locations (CRWMS M\&O 1996).

For the C-Well Pipeline, an ESP along the Midway Valley road (Figure 2, C-Well Reference Area) was chosen due to its proximity (about $0.4 \mathrm{~km}$ ) to the trench and similarity to the area around the trench. For the UE-25 Large Rocks Test Site, an ESP approximately $2.75 \mathrm{~km}$ from the site (Figure 3, Large Rocks Reference Area) was chosen as the nearest area that was similar in vegetation, slope, and elevation. For the GSF Test Pits, an ESP in southern Midway Valley (Figure 2, GSF Test Pit Reference Area) was chosen because of its similarity in vegetation and central location among the test pits. Test pits were within $1.25 \mathrm{~km}$ of the reference area.

\subsubsection{Reference Area Samples}

When the ESPs were established, four (Large Rocks reference area) or five (C-Well and GSF Test Pit reference area) $200-\mathrm{m}$ lines were laid out parallel to a baseline. Two randomly located $50-\mathrm{m}$ transects were established on each line. Two cover points were taken at meter intervals along the $50-\mathrm{m}$ transects (100 points per transect) with an optical cover scope. To sample density and species richness, $252 \times 2-\mathrm{m}$ quadrats were placed along the $50-\mathrm{m}$ transects. All perennial plants rooted in each quadrat were counted and recorded by species. Density and species richness were sampled on each ESP in 1991 and 1992, and cover was sampled yearly from 1989 to 1994.

Perennial plant cover was averaged over the eight or ten $50-\mathrm{m}$ transects within an ESP and across years to get representative means for comparison to the reclaimed sites. Mean density and species richness were calculated from a subset of data for each reference area. The subset was built from the $2 \times 2-\mathrm{m}$ quadrats to equal the size of each respective reclaimed site. For the C-Well 
Pipeline, Large Rocks Test Site, and GSF Test Pit reference areas, density and species richness were calculated for $600 \mathrm{~m}^{2}, 280 \mathrm{~m}^{2}$, and $200 \mathrm{~m}^{2}$, respectively. Values were averaged across 1991 and 1992 to get representative means for the reference areas.

\subsection{MONITORING}

Success parameters and key attributes were monitored on all reclaimed sites in 2000 , six growing seasons after seedling emergence. Sites were also photographed in 2000 to help show the condition of vegetation (Figures 4-7). Seedling emergence occurred on all 31 sites in 1995. From 1995 - 1999 monitoring efforts varied among sites. The C-Well Pipeline was monitored in 1998, the Large Rocks Test Site yearly from 1997 to 1999, and the GSF Test Pits in 1998 and 1999.

At all sites, plant cover and density were evaluated using $1 \times 1-\mathrm{m}$ quadrats that were placed at random in the reclaimed area (10 to 15 quadrats depending on the site). Cover was estimated and density was counted in each quadrat. Means for a site were calculated from the quadrat values. Species richness was determined by counting all native perennial plant species found in the reclaimed area. Observations were recorded regarding erosion, recruitment, reproduction, exotic species, vegetation pattern, and animal use. These observations were recorded in 1999 for the Large Rocks Test Site.

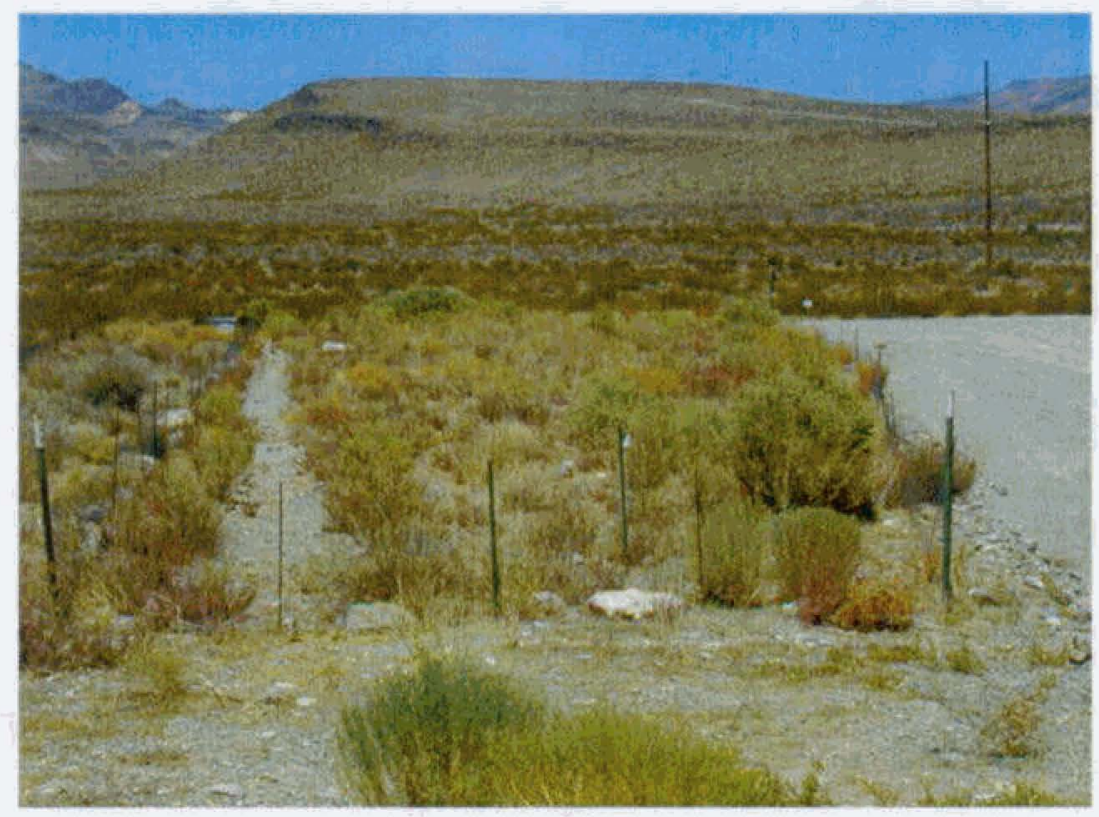

NOTES: The reclaimed area is fenced. The site was recommended for release from further monitoring

Figure 4. C-WELL Pipeline in the Summer of 2000, Six Growing Seasons after Reclamation 


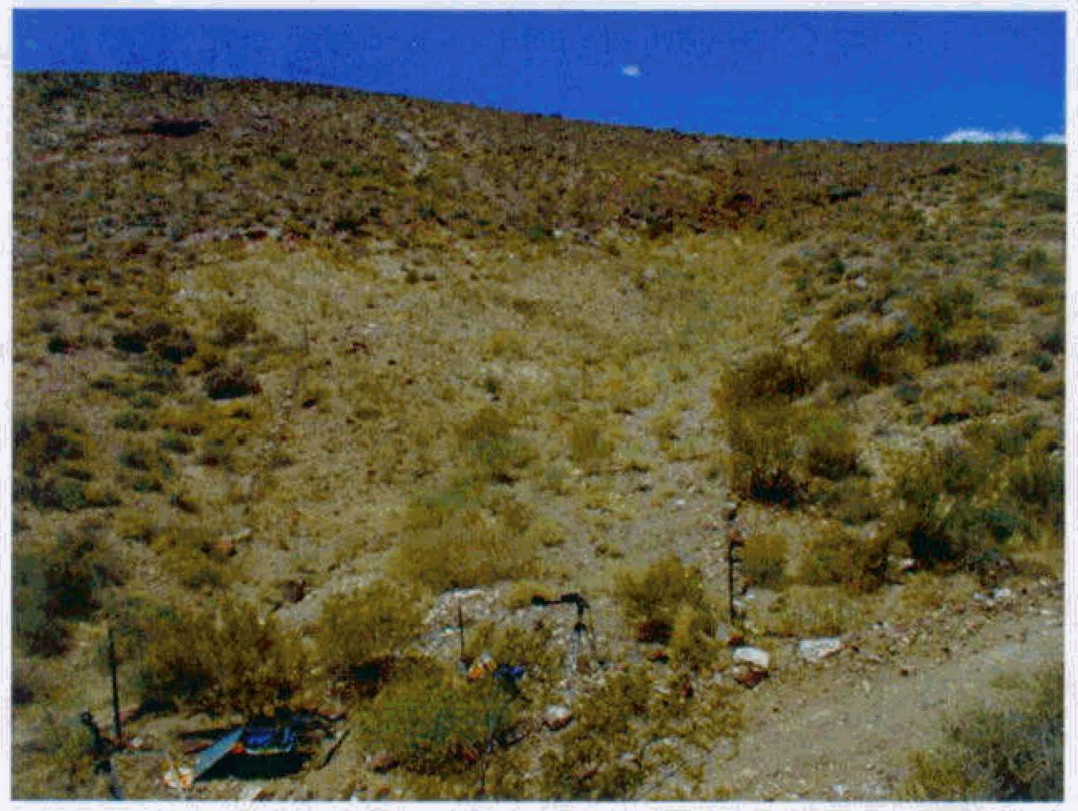

NOTES: The reclaimed area is fenced. The site was recommended for release from further monitoring

Figure 5. Large Rocks Test Site in the Summer of 2000, Six Growing Seasons after Reclamation 


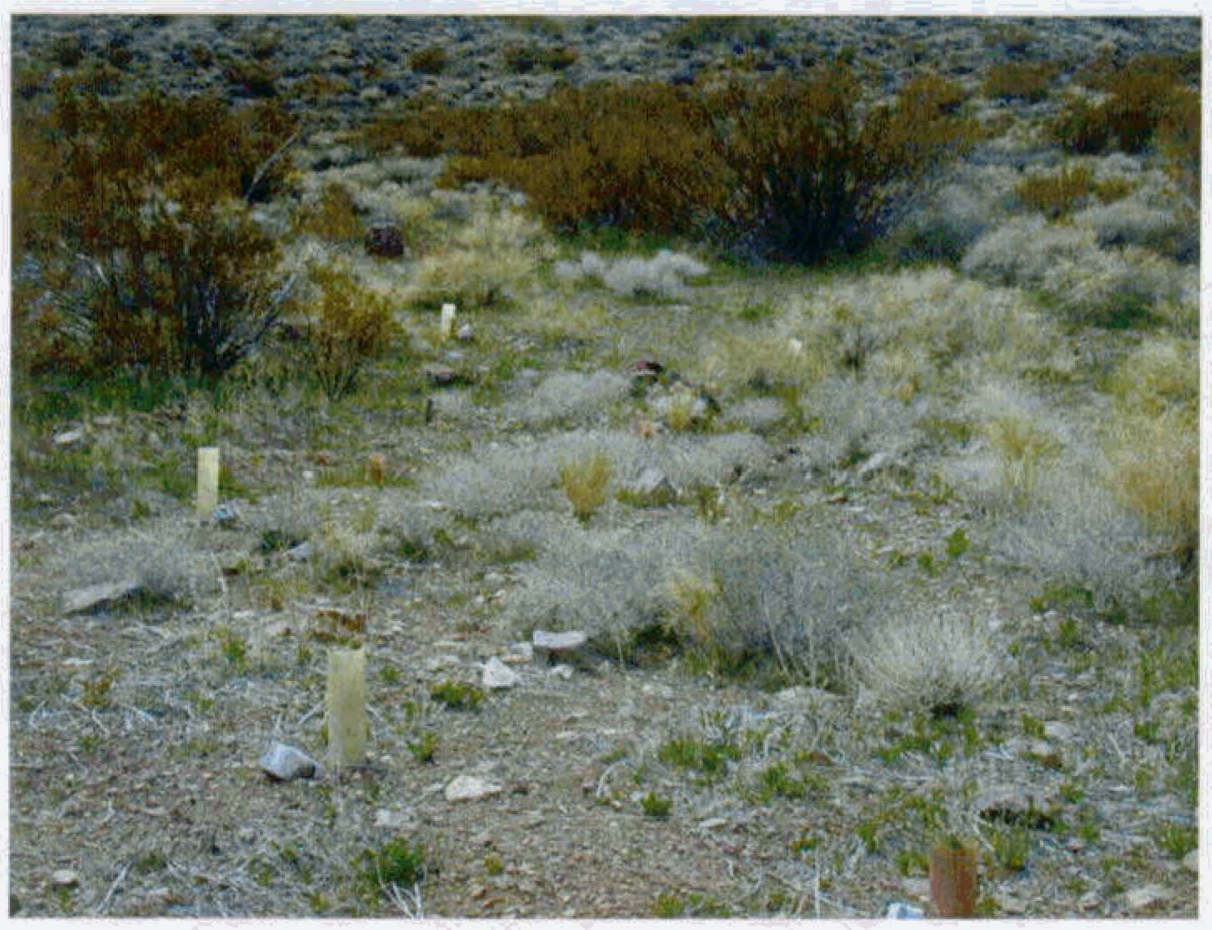

NOTES: The reclaimed pit is visible in the foreground. The site was recommended for release from further monitoring.

Figure 6. UE-25 GSF TP \#24 in the Summer of 2000 , Six Growing Seasons after Reclamation 


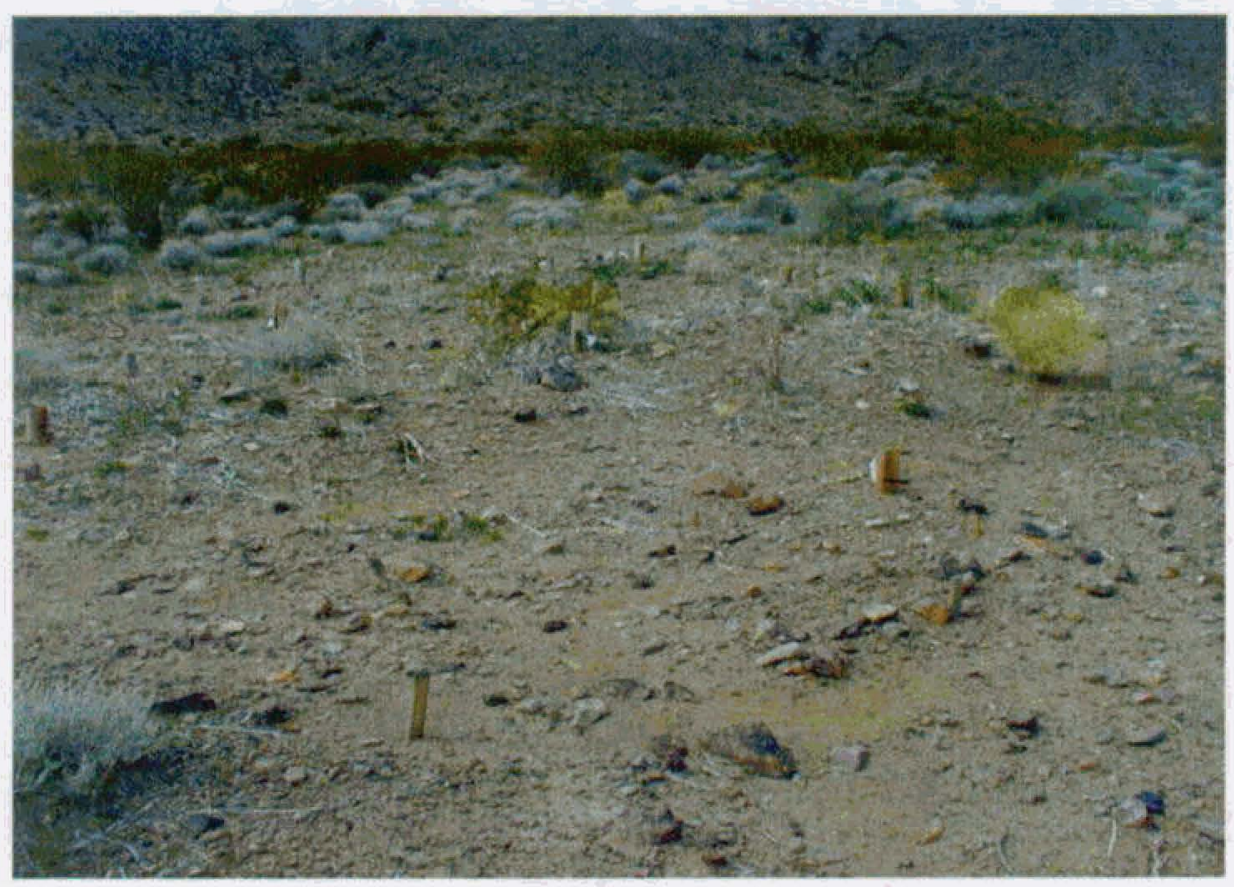

NOTE: Because of low plant density and cover on the pit, the site was not recommended for release from further monitoring.

Figure 7. UE-25 GSF TP \#20 in the Summer of 2000 , Six Growing Seasons after Reclamation

\section{RESULTS AND SITE RELEASE RECOMMENDATIONS}

\subsection{C-WELL PIPELINE}

Mean density estimates showed a decrease from approximately 17 to 8 plants $/ \mathrm{m}^{2}$ from 1998 to 2000 (Figure 8a). Density estimates in 2000 were higher than the success criterion of $0.4 \mathrm{plants} / \mathrm{m}^{2}$. The mean reference area density was $<1 \mathrm{plant} / \mathrm{m}^{2}$, indicating that additional decreases in plant density can be expected at this site.

Mean plant cover was estimated at approximately 20 percent in 1998 and 2000 (Figure 8 b). These values were higher than the average cover of 11 percent for the reference area and well above the calculated criterion of 7 percent (Figure $8 \mathrm{~b}$ ). These data indicate that the cover criterion for this site was met four years after reclamation and was maintained over three years. Thus, conditions were adequate for plant growth at this site.

The number of species on site increased from 10 to 12 over the monitoring period (Figure $8 \mathrm{c}$ ). Eighteen species were noted on the reference area. However, the 60 percent criterion of 11 species was exceeded in 2000.

No signs of erosion were observed, indicating soil stabilization was accomplished. Seven perennial species exhibited signs of flowering indicating reproduction processes were in place. Additionally, small mammal burrows were observed on the site. One exotic species, Bromus 
rubens (red brome), was listed as common on the site, but adequate perennial species richness (Appendix A) and cover should function to prevent further increases. Cover, density, and species richness values exceeded the 60 percent criteria indicating the site was progressing towards an acceptable level of recovery (See Figure 4 for site photograph). Based on these results, the site should be released from further monitoring.

\subsection{UE-25 LARGE ROCKS TEST SITE}

Initial seedling density measured in 1995 averaged 58 plants $/ \mathrm{m}^{2}$ (data not shown). This was probably due to the unusually high seeding rate $(42 \mathrm{~kg}$ PLS/ha). The site was reclaimed prior to seeding rate studies which demonstrated that over time, rates of $20 \mathrm{~kg}$ PLS/ha resulted in similar plant densities to rates of $42 \mathrm{~kg}$ PLS/ha (CRWMS M\&O 1998). Densities had decreased to approximately 8 plants $/ \mathrm{m}^{2}$ by 1997 , remained relatively stable for three years, then decreased to approximately 6 plants $/ \mathrm{m}^{2}$ in 2000 (Figure 9a). This exceeded the criterion of 0.4 plants $/ \mathrm{m}^{2}$ and was more than six times the mean density of the reference area. Thus, additional thinning will likely occur over time due to competition as plants grow.

Mean cover estimates increased from approximately 9 to 15 percent from 1998 to 2000 (Figure 9b), indicating adequate growth conditions at the site over the three year time period. Plant cover was greater than the criterion of 7 percent for the three monitoring sessions and above the mean cover of the reference area in 2000 (Figure $9 \mathrm{~b}$ ).

Fourteen species were observed on the site in 1998 (Figure 9c). This increased by one in 1999 and remained unchanged in 2000 . Species richness for the reference area and the criterion was 14 and 9, respectively. Thus, the site supported an adequate number of species for at least three years and exhibited recruitment of one additional species in the second year of monitoring (See Appendix A for perennial species list).

No evidence of erosion or animal use was observed during the 1999 monitoring session. Therefore, while soil was stabilized, animals had not yet migrated into the site. At least six perennial species flowered in 1999, with only one exotic weed (B. rubens) present in low densities. Cover, density, and species richness values exceeded the 60 percent criteria indicating the site was progressing towards an acceptable level of recovery (See Figure 5 for site photograph). Based on these results, this site should be released from further monitoring.

\subsection{UE-25 GSF TEST PITS}

Yearly trends in success parameters differed somewhat among the 29 GSF Pits. Trends in plant density were similar to those of the $\mathrm{C}$-Well Pipeline and Large Rocks Test sites with consistent yearly decreases for 20 pits (Table 4). Density decreased on five pits from the first monitoring year to the last but increased in the middle year, showed no change on three pits, and increased on one pit. Density was equal to or above the criterion of 0.3 plants $/ \mathrm{m}^{2}$ for 26 of the 29 pits in 2000 (Figure 10a). Twenty four of those were equal to or greater than the reference area mean $\left(0.5\right.$ plants $\left./ \mathrm{m}^{2}\right)$ indicating continued decreases in plant density should be expected on those sites.

Seventeen pits exhibited consistent yearly increases in estimated plant cover (Table 4). Five pits increased from the first monitoring year to the last, but decreased in the middle year. Six sites decreased in cover from the first to last monitoring session, three showed consistent yearly 
decrease while the remaining three decreased only in the last year. In 2000, estimated cover was above the criterion of 6.6 percent for 21 of the test pits, nine of which had cover equal to or above the reference area mean of $11.0 \%$ (Figure 10b).

Trends in species richness were more variable than those for cover and density (see Appendix A for perennial species list). Thirteen pits had consistent yearly increases in the number of species present, eight increased from the first monitoring year to last but decreased in the middle year, three decreased, and three showed no change (Table 4). Species richness was equal to or greater than the criterion (seven species) for 23 of the 29 pits and was only one or two species short for the remaining six pits (Figure 10c).

Some of the variability in trend among sites was probably due to the qualitative methods used, but may also be representative of how site dynamics change as area decreases. Pits were small $($ mean $=0.019 \mathrm{ha})$, and variable in size (range $=0.01-0.03 \mathrm{ha})$ and shape. These factors probably contributed to stochastic effects, such that many of the differences among pits had little to do with reclamation treatments. Similarly, values for individual success parameters that were below the success criteria probably had little to do with reclamation treatments. 

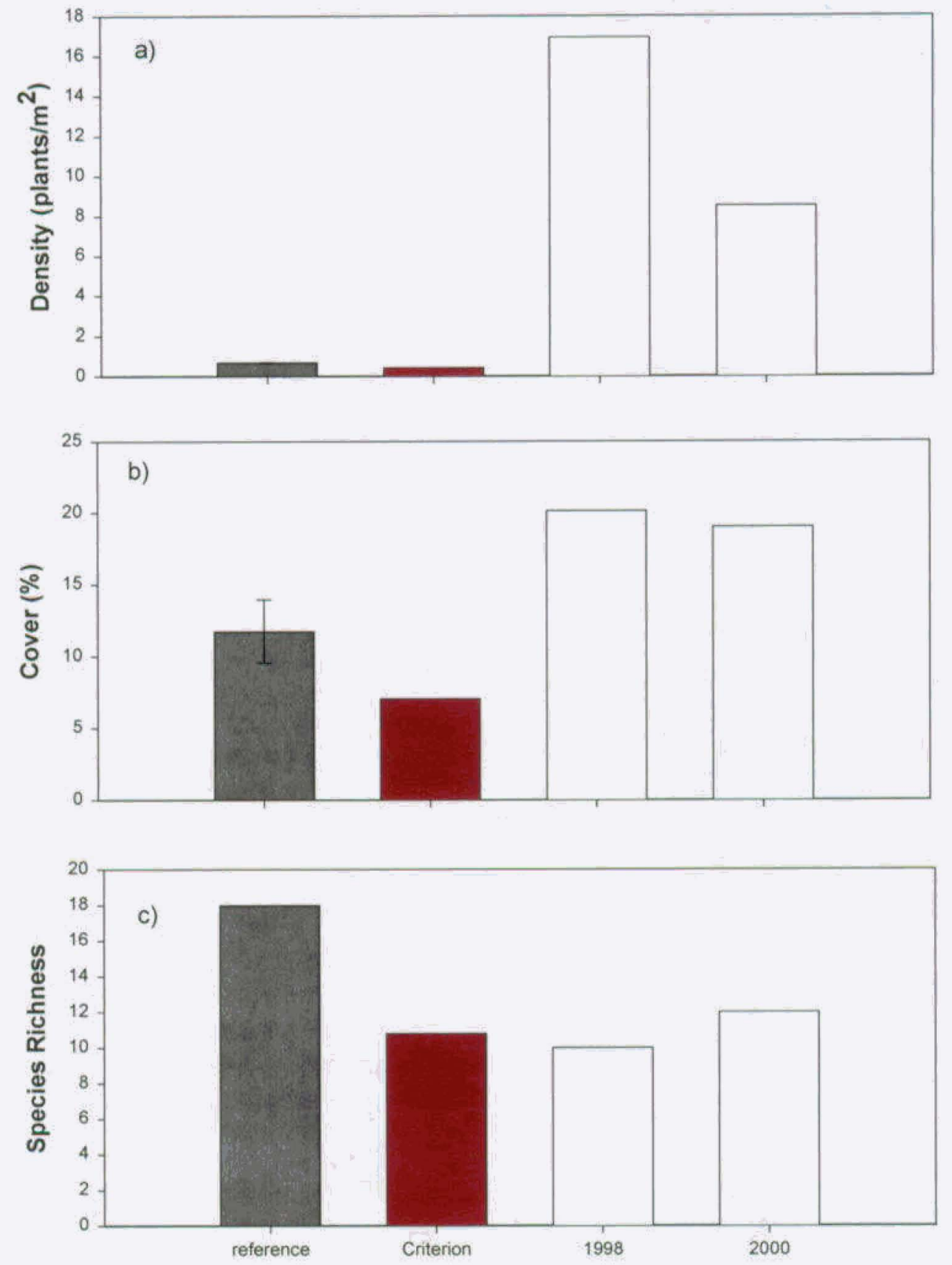

DTN: MO0103SEPQVPDS.000

NOTE: Bars are standard errors of the reference area means. Criterion is 60 percent of the measured parameter on the reference area.

Figure 8. Means for a) Density, b) Cover, and c) Species Richness on C-Well Pipeline and Its Associated Reference Area 

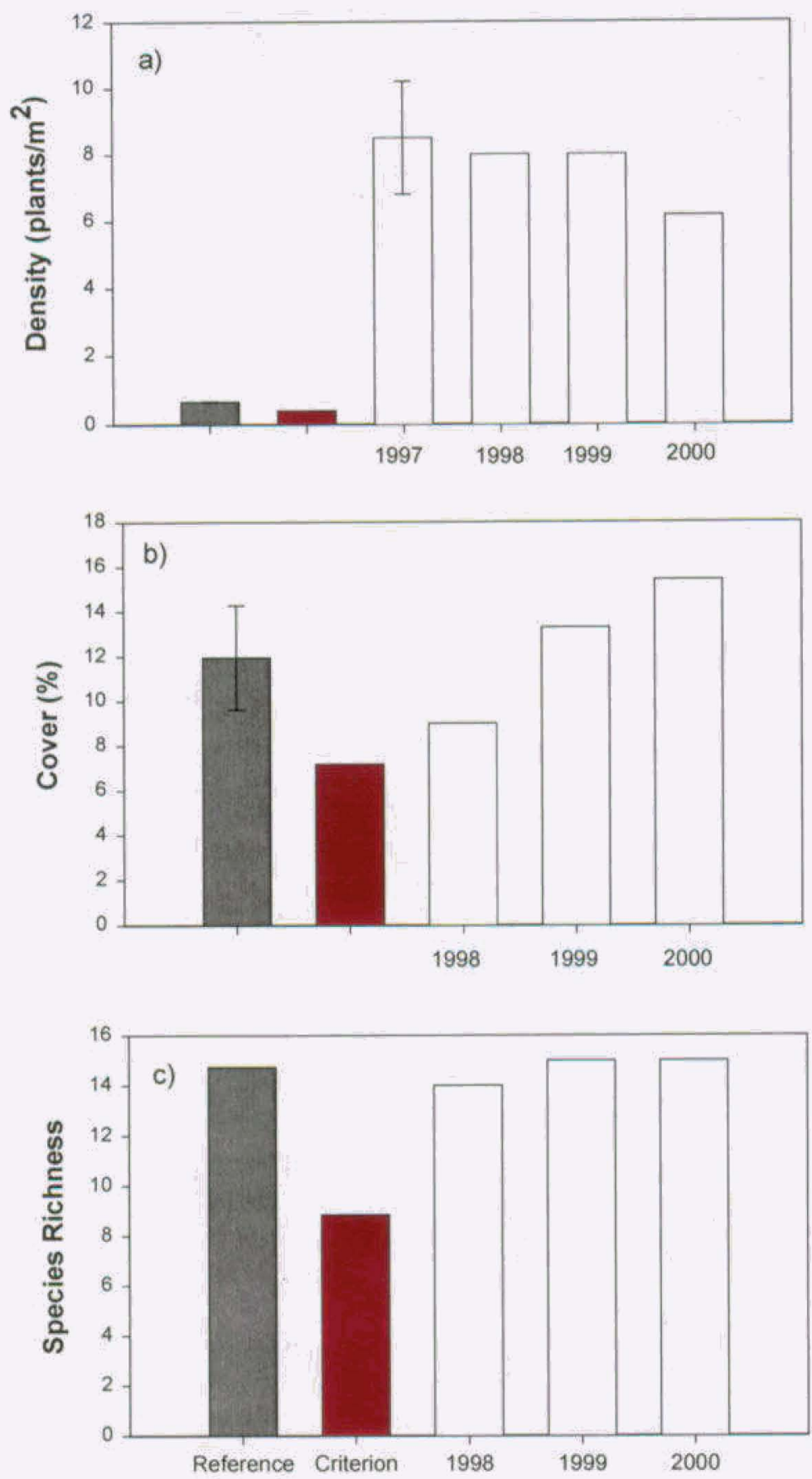

DTN: MO0103SEPQVPDS.000

NOTE: Bars are standard errors of the means. Criterion is 60 percent of the measured parameter on the reference area.

Figure 9. Means for a) Density, b) Cover, and c) Species Richness on UE-25 Large Rocks Test Site and Its Associated Reference Area 
Table 4. Cover, Density, and Species Richness for UE-25 GSF Test Pits for 1998, 1999, and 2000

\begin{tabular}{|c|c|c|c|c|c|c|c|c|c|c|}
\hline \multirow[b]{2}{*}{ Site Name } & \multirow[b]{2}{*}{$\begin{array}{c}\text { Disturbance } \\
\text { Area (ha) } \\
\end{array}$} & \multicolumn{3}{|c|}{$\begin{array}{c}\text { Cover } \\
(\%)\end{array}$} & \multicolumn{3}{|c|}{$\begin{array}{c}\text { Density } \\
\text { (plants/m²) }\end{array}$} & \multicolumn{3}{|c|}{$\begin{array}{l}\text { Species Richness } \\
\text { (\# of plant species) }\end{array}$} \\
\hline & & 1998 & 1999 & 2000 & 1998 & 1999 & 2000 & 1998 & 1999 & 2000 \\
\hline UE-25 GSF-TP 5 & 0.030 & 2.5 & 6.0 & 10.3 & 1.0 & 1.0 & 1.0 & -1 & 3 & 8 \\
\hline UE-25 GSF-TP 6 & 0.014 & 2.5 & 8.0 & $32.0^{\circ}$ & 1.0 & 1.6 & 2.0 & 6 & 5 & 5 \\
\hline UE-25 GSF-TP 7 & 0.014 & 2.0 & 6.8 & 12.1 & 1.5 & 1.2 & 1.0 & 4 & 6 & 6 \\
\hline UE-25 GSF-TP 11 & 0.027 & - & 5.9 & 5.0 & - & 2.2 & 0.3 & - & 6 & 11 \\
\hline UE-25 GSF-TP 12 & 0.020 & 2.0 & 2.5 & 15.0 & 1.0 & 1.4 & 0.3 & 5 & 4 & 6 \\
\hline UE-25 GSF-TP 13 & 0.010 & 3.0 & 3.4 & 5.0 & 4.0 & 1.8 & 1.0 & 5 & 5 & 5 \\
\hline UE-25 GSF-TP 14 & 0.016 & 7.5 & 12.0 & 15.0 & 5.0 & 3.1 & 0.9 & 6 & 6 & 7 \\
\hline UE-25 GSF-TP 16 & 0.032 & 2.0 & 4.9 & 10.0 & 3.4 & 2.6 & 0.5 & 7 & 6 & 8 \\
\hline UE-25 GSF-TP 17 & 0.015 & 2.0 & 5.2 & 10.0 & 2.0 & 2.2 & 0.5 & 7 & 9 & 7 \\
\hline UE-25 GSF-TP 18 & 0.016 & 4.5 & 9.3 & 20.0 & 4.0 & 4.8 & 0.9 & - & 5 & 7 \\
\hline UE-25 GSF-TP 19 & 0.016 & 1.2 & 3.0 & 1.0 & 0.8 & 1.4 & 0.2 & 4 & 6 & 7 \\
\hline UE-25 GSF-TP 20 & 0.023 & 1.1 & 1.0 & 1.0 & 0.8 & 0.6 & 0.1 & 7 & 7 & 7 \\
\hline UE-25 GSF-TP 22 & 0.017 & 9.6 & 12.8 & 10.0 & 2.4 & 3.4 & 0.7 & 6 & 5 & 10 \\
\hline UE-25 GSF-TP 23 & 0.024 & 7.7 & 3.8 & 5.0 & 2.1 & 1.3 & 0.5 & 5 & 5 & 7 \\
\hline UE-25 GSF-TP 24 & 0.018 & 2.5 & 5.0 & 10.0 & 2.0 & 1.4 & 0.5 & 8 & 7 & 9 \\
\hline UE-25 GSF-TP 26 & 0.015 & 3.3 & 8.7 & 20.0 & 1.0 & 2.4 & 0.9 & 5 & 9 & 11 \\
\hline UE-25 GSF-TP 27 & 0.012 & 3.0 & 3.7 & 10.0 & 1.0 & 1.1 & 1.0 & 5 & 7 & 10 \\
\hline UE-25 GSF-TP 28 & 0.016 & 10.0 & 4.0 & 20.0 & 6.0 & 2.2 & 0.7 & 7 & 7 & 7 \\
\hline UE-25 GSF-TP 29 & 0.019 & 11.3 & 5.4 & 10.0 & 3.9 & 1.5 & 0.8 & 7 & 5 & 7 \\
\hline UE-25 GSF-TP 30 & 0.020 & 13.0 & 6.1 & 15.0 & 8.0 & 5.7 & 0.9 & 9 & 14 & 11 \\
\hline UE-25 GSF-TP 31 & 0.026 & 1.0 & 0.3 & 1.0 & - & 0.3 & 0.2 & 10 & 8 & 11 \\
\hline UE-25 GSF-TP 32 & 0.013 & 17.0 & 5.1 & 10.0 & 3.2 & 2.9 & 0.8 & 6 & 6 & 8 \\
\hline UE-25 GSF-TP 33 & 0.021 & 9.0 & 6.5 & 10.0 & 1.8 & 1.8 & 0.6 & 5 & 7 & 8 \\
\hline UE-25 GSF-TP 34 & 0.016 & 1.5 & 4.1 & 5.0 & 1.0 & 2.1 & 0.5 & 8 & 6 & 10 \\
\hline UE-25 GSF-TP 35 & 0.022 & 3.0 & 10.9 & 10.0 & 2.5 & 6.4 & 0.6 & 8 & 9 & 11 \\
\hline UE-25 GSF-TP 36 & 0.017 & 3.0 & 7.2 & 11.6 & 5.0 & 3.6 & 2.6 & 6 & 5 & 6 \\
\hline UE-25 GSF-TP 37 & 0.022 & 2.0 & 4.5 & 3.4 & 2.7 & 1.1 & 0.9 & 6 & 6 & 5 \\
\hline UE-25 GSF-TP 38 & 0.017 & 1.0 & 3.4 & 8.5 & 1.5 & 1.6 & 1.1 & 6 & 5 & 7 \\
\hline UE-25 GSF-TP 39 & 0.019 & 2.0 & 2.4 & 10.1 & 1.5 & 1.0 & 1.0 & 9 & 8 & 9 \\
\hline mean & 0.019 & 4.7 & 5.6 & 10.6 & 2.6 & 2.2 & 0.8 & 6 & 6 & 8 \\
\hline
\end{tabular}

NOTE: ${ }^{1}$ no data available 

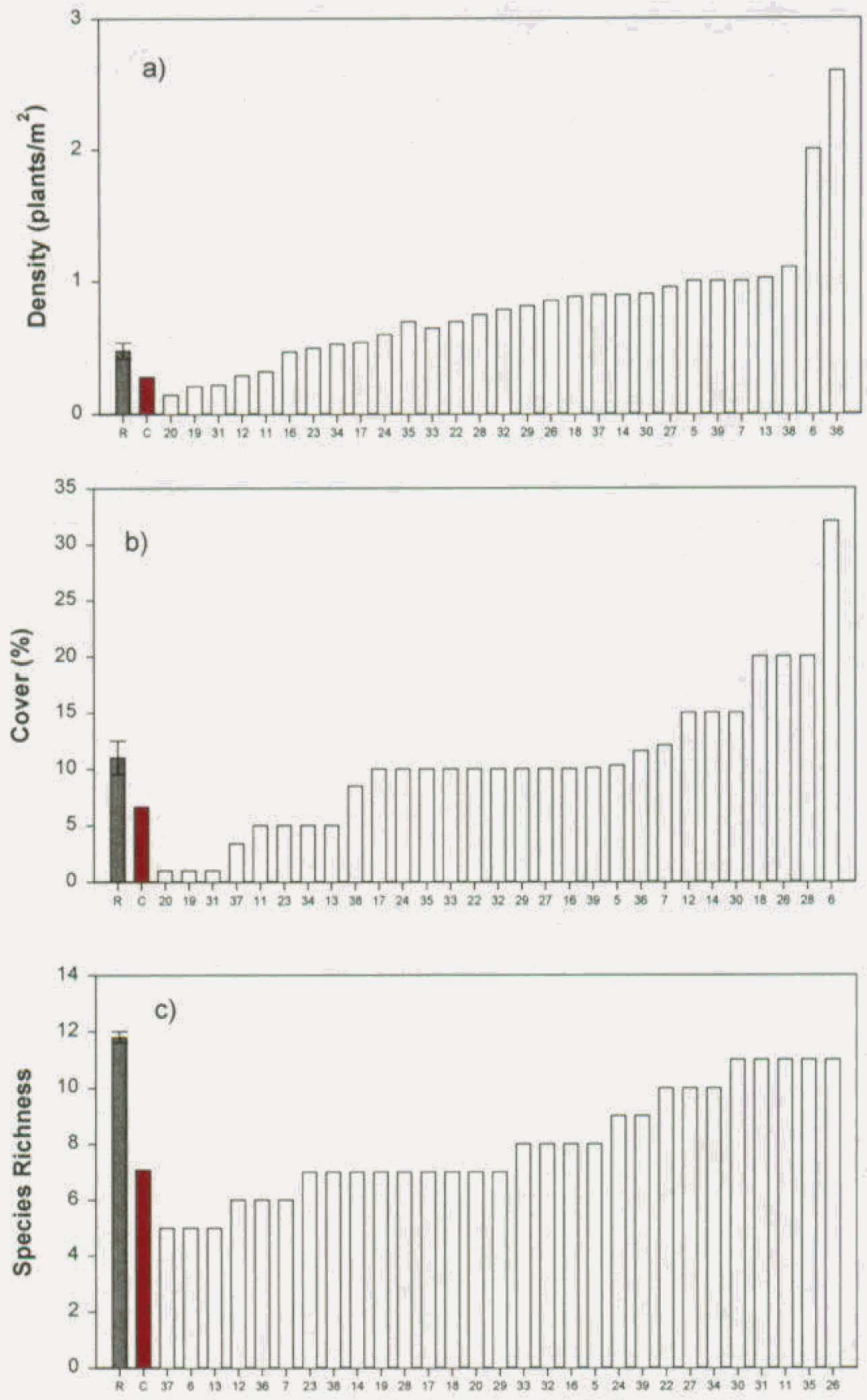

DTN: MO0103SEPQVPDS.000

NOTES: Pit identification numbers are on the $x$-axis. Bars are standard errors of the reference area means. $\mathrm{R}=$ reference area, $\mathrm{C}=60$ percent criterion.

Figure 10. Means for a) Density, b) Cover, and c) Species Richness on GSF Test Pits and Their Associated Reference Areas 
Cover was below the criterion for eight of the 29 pits. However, density was above the criterion for five of those pits $(11,13,23,34$, and 37$)$ and no erosion was observed, suggesting soil stabilization and adequate conditions for establishment. Given time, those existing plants are likely to increase in cover. Additionally, three to eight species were flowering on these pits indicating potential for plant recruitment. Therefore, these five pits and the 21 pits that met the success criteria should be released from further monitoring (see Figure 6 for representative photograph of successfully reclaimed test pits).

Both cover and density were below the criteria on pit 31 (Figure 10). However, this pit was on a gravel ridge within a wash. Naturally high gravel content combined with periodic flash flooding in the wash are likely limitations to plant growth and persistence at this site. Vegetation patterns were similar to other small established patches in the area indicating naturally low cover and density. Additionally, ten perennial species had established on the site, seven of which were flowering when monitoring occurred in 2000. Based on this combined information, pit 31 is progressing towards a level of recovery comparable to the potential of the site and should be released from further monitoring.

Cover and density were also below the criteria on pits 19 and 20 (Figure 10). Cover was estimated at 1 percent for both sites, while density was estimated at 0.21 and 0.14 plants $/ \mathrm{m}^{2}$ for pits 19 and 20, respectively. These values are exceedingly low compared to the criteria (see Figure 7 for representative photograph). Seven perennial species were observed at both sites (Appendix A); however, they were listed as rare or widely scattered. At pit 19 B. rubens was common, suggesting the possibility of an exotic weed problem. At pit 20 the presence of two exotic weed species was noted ( $B$. rubens and Salsola kali [Russian thistle]) but these were rare to widely scattered. Based on the success parameter values and attributes for these two sites, remediation was performed in 2001 and another year of monitoring is recommended.

\section{SUMMARY}

Twenty nine of the 31 sites that were six growing seasons old in 2000 exhibited characteristics that suggested an acceptable level of recovery had been reached and are recommended for release from further monitoring. GSF Test Pits 19 and 20 had low plant cover, low density, and key attributes that were of concern. These sites are not recommended for release and were remediated with addition of transplants in 2001.

\section{REFERENCES}

\subsection{DOCUMENTS CITED}

Barbour, M.G., Burk, J. H., and Pitts, W.D. 1980. Terrestrial Plant Ecology. Menlo Park, California: Benjamin/Cummings Publishing Company. TIC: 243042.

Buchanan, C.C. 1997. "Final Biological Opinion for Reinitiation of Formal Consultation for Yucca Mountain Site Characterization Studies." Letter from C.C. Buchanan (Department of the Interior) to W. Dixon (DOE/YMSCO), July 23, 1997, File No. 1-5-96-F-307R.

ACC: MOL.19980302.0368. 
Cole, D.N. and Landres, P.B. 1996. "Threats to Wilderness Ecosytems: Impacts and Research Needs." Ecological Applications, 6, (1), 168-184. Tempe, Arizona: Ecological Society of America. TIC: 249550.

CRWMS M\&O (Civilian Radioactive Waste Management System Management and Operating Contractor) 2000. Biological Resources. Activity Evaluation, September 28, 2000. Las Vegas, Nevada: CRWMS M\&O. ACC: MOL.20001011.0098.

CRWMS M\&O 1998. Progress Report: Recovery Status of Vegetation on Reclamation Study Sites at Yucca Mountain, Nevada. Las Vegas, Nevada: CRWMS M\&O.

ACC: MOL.1990308.0107.

CRWMS M\&O 1996. The Vegetation of Yucca Mountain: Description and Ecology. B00000000-01717-5705-00030 Rev 00. Las Vegas, Nevada: CRWMS M\&O.

ACC: MOL.19970116.0055.

Dixon, W.R. 1998. "Reclamation Standard and Monitoring Plan (RSMP) for the Yucca Mountain Site Characterization Project." Letter from W.R. Dixon (DOE/YMSCO) to R.D. Williams (U.S. Fish and Wildlife Service), August 13, 1998, with enclosure.

ACC: MOL.19980923.0029; MOL.19980923.0030.

DOE (U.S. Department of Energy) 2000. Quality Assurance Requirements and Description. DOE/RW-0333P, Rev. 10. Washington, D.C.: U.S. Department of Energy, Office of Civilian Radioactive Waste Management. ACC: MOL.20000427.0422.

Greig-Smith, P. 1983. "Pattern." In Quantitative Plant Ecology, Chapter 3 of Studies in Ecology, Volume 9. Third Edition. Berkeley, California: University of California Press, 1983. TIC: 249551 .

Kershaw, K. A. and Looney, J.H. 1985. Quantitative and Dynamic Plant Ecology. 3rd Edition. 121-155. Baltimore, Maryland: Edward Arnold. TIC: 249552.

Smith, S.D., Herr, C.A., Leary, K.L., and Piorkowski, J.M. 1995. "Soil-Plant Water Relations in a Mojave Desert Mixed Shrub Community. A Comparison of Three Geomorphic Surfaces." Journal of Arid Environments 29, (3), 339-351. New York, New York: Academic Press. TIC: 240834.

YMP (Yucca Mountain Site Characterization Project) 2001. Reclamation Implementation Plan, YMP/91-14 Rev 2. Las Vegas, Nevada: Yucca Mountain Site Characterization Office.

ACC: MOL.20010301.0238.

\subsection{CODES, STANDARDS, REGULATIONS, AND PROCEDURES}

AP-2.21Q, Rev 0, ICN 0. Quality Determinations and Planning for Scientific, Engineering, and Regulatory Compliance Activities. Washington, D.C.: U.S. Department of Energy, Office of Civilian Radioactive Waste Management. ACC: MOL.20000802.0003. 


\subsection{SOURCE DATA, LISTED BY DATA TRACKING NUMBER}

MO0102COV00340.000. Land Surface Disturbances Documented Prior to and After June, 1991. Submittal date: 02/16/2001.

MO0103SEPQVPDS.000. Qualitative Vegetation Monitoring - Plant Cover, Density, and Species Richness for 1998, 1999, and 2000. Submittal date: 03/14/2001. 
APPENDIX A

PLANT SPECIES ON RECLAMATION SITES 


\section{APPENDIX A}

\section{PLANT SPECIES ON RECLAMATION SITES}

Table A-1. Native Perennial Plant Species on Reclamation Sites in 2000. See Table A-2 for common names.

\begin{tabular}{|c|c|}
\hline Site & Species Present \\
\hline NSCA.C-well.pipeline & $\begin{array}{l}\text { Achnatherum hymenoides, Ambrosia dumosa, Atriplex canescens, Ericameria } \\
\text { nauseosa, Ephedra nevadensis, Eriogonum fasciculatum, Hymenoclea } \\
\text { salsola, Lycium andersonii, Krascheninnikovia lanata, Larrea tridentata, } \\
\text { Stephanomeria pauciflora, Sphaeralcea ambigua }\end{array}$ \\
\hline Large Rocks Test Site & $\begin{array}{l}\text { Achnatherum hymenoides, Ambrosia dumosa, Atriplex canescens, Atriplex } \\
\text { confertifolia, Chrysothamnus viscidiflorus, Coleogyne ramosissima, Ephedra } \\
\text { nevadensis, Ericameria nauseosa, Hymenoclea salsola, Krascheninnikovia } \\
\text { lanata, Lycium andersonii, Sphaeralcea ambigua }\end{array}$ \\
\hline UE-25 GSF TP \#5 & $\begin{array}{l}\text { Ambrosia dumosa, Ephedra nevadensis, Enicameria cooperi, Ericameria } \\
\text { teretifolia, Hymenoclea salsola, Larrea tridentata, Lycium andersonii, } \\
\text { Sphaeralcea ambigua }\end{array}$ \\
\hline UE-25 GSF TP \#6 & $\begin{array}{l}\text { Ambrosia dumosa, Chrysothamnus viscidiflorus, Ericameria teretifolia, } \\
\text { Hymenoclea salsola, Larrea tridentata }\end{array}$ \\
\hline UE-25 GSF TP \#7 & $\begin{array}{l}\text { Ambrosia dumosa, Atriplex canescens, Hymenoclea salsola, Krameria erecta, } \\
\text { Sphaeralcea ambigua, Stephanomeria pauciflora }\end{array}$ \\
\hline UE-25 GSF TP \#11 & $\begin{array}{l}\text { Acamptopappus shockleyi, Achnatherum hymenoides, Achnatherum } \\
\text { speciosum, Ambrosia dumosa, Atriplex canescens, Elymus elymoides, } \\
\text { Hymenoclea salsola, Larrea tridentata, Opuntia erinacea, Salazaria mexicana, } \\
\text { Sphaeralcea ambigua }\end{array}$ \\
\hline UE-25 GSF TP \#12 & $\begin{array}{l}\text { Ambrosia dumosa, Ericameria cooperi, Hymenoclea salsola, Larrea tridentata, } \\
\text { Salazaria mexicana }\end{array}$ \\
\hline UE-25 GSF TP \#13 & $\begin{array}{l}\text { Ambrosia dumosa, Atriplex canescens, Hymenoclea salsola, Larrea tridentata, } \\
\text { Sphaeralcea ambigua }\end{array}$ \\
\hline UE-25 GSF TP \#14 & $\begin{array}{l}\text { Achnatherum hymenoides, Ambrosia dumosa, Atriplex canescens, } \\
\text { Hymenoclea salsola, Larrea tridentata, Sphaeralcea ambigua }\end{array}$ \\
\hline UE-25 GSF TP \#16 & $\begin{array}{l}\text { Ambrosia dumosa, Atriplex canescens, Ephedra nevadensis, Hymenoclea } \\
\text { salsola, Larrea tridentata, Sphaeralcea ambigua, Stephanomeria pauciflora, } \\
\text { xylorhiza tortifolia }\end{array}$ \\
\hline UE-25 GSF TP \#17 & $\begin{array}{l}\text { Ambrosia dumosa, Atriplex canescens, Ericameria cooperi, Ericameria } \\
\text { teretifolia, Hymenoclea salsola, Larrea tridentata, Menodora spinescens }\end{array}$ \\
\hline UE-25 GSF TP \#18 & $\begin{array}{l}\text { Ambrosia dumosa, Atriplex canescens, Ephedra nevadensis, Hymenoclea } \\
\text { salsola, Larrea tridentata, Menodora spinescens, Sphaeralcea ambigua }\end{array}$ \\
\hline UE-25 GSF TP \#19 & $\begin{array}{l}\text { Ambrosia dumosa, Ephedra nevadensis, Ericameria teretifolia, Hymenoclea } \\
\text { salsola, Larrea tridentata, Larrea tridentata, Stephanomeria pauciflora }\end{array}$ \\
\hline UE-25 GSF TP \#20 & $\begin{array}{l}\text { Ambrosia dumosa, Ericameria teretifolia, Hymenoclea salsola, Larrea } \\
\text { tridentata, Lycium andersonii, Sphaeralcea ambigua, Stephanomeria } \\
\text { pauciflora }\end{array}$ \\
\hline UE-25 GSF TP \#22 & $\begin{array}{l}\text { Ambrosia dumosa, Atriplex canescens, Encelia virginensis, Ericameria } \\
\text { cooperi, Hymenoclea salsola, Larrea tridentata, Lycium andersonii, Salazaria } \\
\text { mexicana, Sphaeralcea ambigua, Stephanomeria pauciflora }\end{array}$ \\
\hline UE-25 GSF TP \#23 & $\begin{array}{l}\text { Ambrosia dumosa, Atriplex canescens, Hymenoclea salsola, Larrea tridentata, } \\
\text { Lycium andersonii, Sphaeralcea ambigua }\end{array}$ \\
\hline UE-25 GSF TP \#24 & $\begin{array}{l}\text { Ambrosia dumosa, Eriogonum fasciculatum, Encelia virginensis, Ephedra } \\
\text { nevadensis, Ericameria teretifolia, Hymenoclea salsola, Larrea tridentata, } \\
\text { Lycium andersonii, Sphaeralcea ambigua }\end{array}$ \\
\hline
\end{tabular}


Table A-1. Native Perennial Plant Species on Reclamation Sites in 2000 (Continued). See Table A-2 for common names.

\begin{tabular}{|c|c|}
\hline Site & Species Present \\
\hline UE-25 GSF TP \#26 & $\begin{array}{l}\text { Achnatherum hymenoides, Ambrosia dumosa, Atriplex canescens, Ephedra } \\
\text { nevadensis, Ericameria teretifolia, Hymenoclea salsola, Krascheninnikovia } \\
\text { lanata, Larrea tridentata, Menodora spinescens, Salazaria mexicana, } \\
\text { Sphaeralcea ambigua }\end{array}$ \\
\hline UE-25 GSF TP \#27 & $\begin{array}{l}\text { Ambrosia dumosa, Ephedra nevadensis, Ericameria cooperi, Ericameria } \\
\text { teretifolia, Hymenoclea salsola, Krascheninnikovia lanata, Larrea tridentata, } \\
\text { Lycium andersonii, Menodora spinescens, Sphaeralcea ambigua, }\end{array}$ \\
\hline UE-25 GSF TP \#28 & $\begin{array}{l}\text { Ambrosia dumosa, Atriplex canescens, Ephedra nevadensis, Hymenoclea } \\
\text { salsola, Larrea tridentata, Sphaeralcea ambigua }\end{array}$ \\
\hline UE-25 GSF TP \#29 & $\begin{array}{l}\text { Ambrosia dumosa, Atriplex canescens, Encelia virginensis, Ephedra } \\
\text { nevadensis, Hymenoclea salsola, Larrea tridentata, Sphaeralcea ambigua }\end{array}$ \\
\hline UE-25 GSF TP \#30 & $\begin{array}{l}\text { Achnatherum hymenoides, Ambrosia dumosa, Atriplex canescens, Ephedra } \\
\text { nevadensis, Ericameria cooperi, Ericameria teretifolia, Hymenoclea salsola, } \\
\text { Larrea tridentata, Lycium andersonii, Salazaria mexicana, Sphaeralcea } \\
\text { ambigua }\end{array}$ \\
\hline UE-25 GSF TP \#31 & $\begin{array}{l}\text { Achnatherum hymenoides, Ambrosia dumosa, Ephedra nevadensis, } \\
\text { Eriogonum fasciculatum, Ericameria teretifolia, Hymenoclea salsola, Larrea } \\
\text { tridentata, Lycium andersonii, Pleuraphis jamesii, Sphaeralcea ambigua, } \\
\text { Stephanomeria pauciflora }\end{array}$ \\
\hline UE-25 GSF TP \#32 & $\begin{array}{l}\text { Ambrosia dumosa, Atriplex canescens, Hymenoclea salsola, Krameria erecta, } \\
\text { Larrea tridentata, Lycium andersonii, Sphaeralcea ambigua, Stephanomeria } \\
\text { pauciflora }\end{array}$ \\
\hline UE-25 GSF TP \#33 & $\begin{array}{l}\text { Achnatherum hymenoides, Ambrosia dumosa, Ericameria teretifolia, } \\
\text { Hymenoclea salsola, Krascheninnikovia lanata, Larrea tridentata, Lycium } \\
\text { andersonii }\end{array}$ \\
\hline UE-25 GSF TP \#34 & $\begin{array}{l}\text { Acnatherum speciosum, Ambrosia dumosa, Atriplex canescens, Ephedra } \\
\text { nevadensis, Hymenoclea salsola, Krameria erecta, Larrea tridentata, Lycium } \\
\text { andersonii, Sphaeralcea ambigua, Stephanomeria pauciflora }\end{array}$ \\
\hline UE-25 GSF TP \#35 & $\begin{array}{l}\text { Ambrosia dumosa, Atriplex canescens, Ephedra nevadensis, Ericameria } \\
\text { cooperi, Eriogonum fasciculatum, Hymenoclea salsola, Larrea tridentata, } \\
\text { Opuntia basilaris, Sphaeralcea ambigua, Stephanomeria pauciflora }\end{array}$ \\
\hline UE-25 GSF TP \#36 & $\begin{array}{l}\text { Ambrosia dumosa, Atriplex canescens, Ericameria teretifolia, Hymenoclea } \\
\text { salsola, Larrea tridentata }\end{array}$ \\
\hline UE-25 GSF TP \#37 & $\begin{array}{l}\text { Ambrosia dumosa, Hymenoclea salsola, Larrea tridentata, Sphaeralcea } \\
\text { ambigua }\end{array}$ \\
\hline UE-25 GSF TP \#38 & $\begin{array}{l}\text { Ambrosia dumosa, Hymenoclea salsola, Larrea tridentata, Lycium andersonii, } \\
\text { Sphaeralcea ambigua, Stephanomeria pauciflora }\end{array}$ \\
\hline UE-25 GSF TP \#39 & $\begin{array}{l}\text { Ambrosia dumosa, Atriplex canescens, Ericameria teretifolia, Guttierrezia } \\
\text { sarothrae, Hymenoclea salsola, Larrea tridentata, Lycium andersonii, } \\
\text { Sphaeralcea ambigua, Stephanomeria pauciflora }\end{array}$ \\
\hline
\end{tabular}


Table A-2. List of Common Names for Species on Reclamation Sites at Yucca Mountain

\begin{tabular}{|c|c|}
\hline Scientific Name & Common Name \\
\hline Acamptopappus shockleyi & Shockley's Goldenhead \\
\hline Achnatherum hymenoides & Indian Ricegrass \\
\hline Achnatherum speciosa & Desert Needlegrass \\
\hline Ambrosia dumosa & White Bursage \\
\hline Atriplex canescens & Fourwing saltbush \\
\hline Atriplex confertifolia & Shadscale \\
\hline Chrysothamnus viscidiflorus & Green Rabbitbrush \\
\hline Coleogyne ramosissima & Blackbrush \\
\hline Elymus elymoides & Bottlebrush Squirreltail \\
\hline Encelia virginensis & Virgin River Brittlebrush \\
\hline Ephedra nevadensis & Nevada Jointfir \\
\hline Ericameria cooperi & Cooper's Heathgoldenrod \\
\hline Ericameria nauseosa & Rubber Rabbitbrush \\
\hline Ericameria teretifolia & Needleleaf Rabbitbrush \\
\hline Eriogonum fasciculatum & California Buckwheat \\
\hline Guttierrezia sarothrae & Broom Snakeweed \\
\hline Hymenoclea salsola & White Burrobrush \\
\hline Krameria erecta & Littleleaf Ratany \\
\hline Krascheninnikovia lanata & Winterfat \\
\hline Larrea tridentata & Creosotebush \\
\hline Lycium andersonii & Anderson's Wolfberry \\
\hline Menodora spinescens & Spiny Menodora \\
\hline Opuntia basilaris & Beavertail Pricklypear \\
\hline Opuntia erinacea & Grizzlybear Pricklypear \\
\hline Salazaria mexicana & Mexican Bladdersage \\
\hline Pleuraphis jamesii & Galleta Grass \\
\hline Sphaeralcea ambigua & Desert Globemallow \\
\hline Stephanomeria pauciflora & Brownplume Wirelettuce \\
\hline
\end{tabular}

